Research Article

\title{
Effect of Doping Metals on the Structure of PEO Coatings on Titanium
}

\author{
Nykolay D. Sakhnenko (D), Maryna V. Ved' (D), and Ann V. Karakurkchi iD \\ National Technical University "Kharkiv Polytechnical Institute", Kyrpychova St. 2, Kharkiv 61002, Ukraine \\ Correspondence should be addressed to Ann V. Karakurkchi; anyutikukr@gmail.com
}

Received 3 February 2018; Revised 30 April 2018; Accepted 17 May 2018; Published 19 June 2018

Academic Editor: Eric Guibal

Copyright @ 2018 Nykolay D. Sakhnenko et al. This is an open access article distributed under the Creative Commons Attribution License, which permits unrestricted use, distribution, and reproduction in any medium, provided the original work is properly cited.

\begin{abstract}
The structure and properties of the oxide films formed on titanium alloys by means of plasma-electrolytic oxidizing in alkali electrolytes based on pyrophosphates, borates, or acetates of alkali metals with the addition of dopants' oxides or oxoanions of varying composition have been studied. Anodic polarization in the spark discharge (microarc) mode at application of interelectrode potential 90 to $160 \mathrm{~V}$ has been used to obtain mixed-oxide systems $\mathrm{TiO}_{x} \cdot \mathrm{WO}_{y}, \mathrm{TiO}_{x} \cdot \mathrm{MoO}_{y}, \mathrm{TiO}_{x} \cdot \mathrm{ZrO}_{2}$, and $\mathrm{TiO}_{x} \cdot \mathrm{V}_{2} \mathrm{O}_{5}$. The possibility to obtain the oxide layers containing the alloying elements by the modification of the composition of electrolytes has been stated. The chemical and phase composition as well as the topography, the microstructure, and the grain size of the formed layers depend on the applied current, interelectrode voltage, and the layer chemical composition. The effect of formed films composition on the resistance of titanium to corrosion has been discussed. Catalytic activity of mixed-oxide systems was determined in the model reaction of methyl orange dye MO photodestruction.
\end{abstract}

\section{Introduction}

Intensive economic activity and increase in the production capacities of different sectors of the industry lead to the growth of the pollution in air and water basins by toxic substances with different nature and chemical stabilities. Given this, the organization of removal of natural and technogenic contaminators from the air and aqueous medium is impossible without effective and accessible catalyst application [1]. Catalytic materials based on titanium oxide found application in the heterogeneous catalysis and especially photocatalysis [2-4]. The introduction of additional components into the composition of oxide layers makes it possible to improve the functional properties and activity of the catalyst and the scope of its application $[5,6]$.

Better technological forms of a catalyst are the thin-film coatings, formed directly on the metal substrate by the method of plasma-electrolytic oxidizing (PEO) [7]. The anodic oxidation in the microarc mode allows formation of different types of titanium oxides and incorporation of electrolyte components into the oxide layers $[8,9]$. Such mixed metal-oxide systems differ with high adhesion to metal substrate and have developed the surface. On the surface relief protrusions of coatings, there are a significant number of active catalytic centers. They are oxides of doped metals, differing in physical and chemical properties and affinity for oxygen $[7,10]$.

The use of electrolytes of different compositions and varying conditions for titanium alloys $\mathrm{PEO}$ treatment allows obtaining coatings doped with transition $[11,12]$, refractory $[13,14]$, rare metals, and dispersed oxides $[15,16]$. So, the studies targeted at improvement of the techniques used for the formation of mixed-oxide coatings on titanium alloys are of great interest.

At the same time, issues of managing the PEO coatings morphology and selection of dopants and their influence on the composition and properties of the formed oxide layers remain unresolved. A successful solution of these problems creates the prerequisites for the formation of coatings that possess an improved resource, a proper chemical resistance to the aggressive media action, prescribed morphology, and catalytic activity $[5,17,18]$. 
TABle 1: Electrolytes for PEO.

\begin{tabular}{lcccc}
\hline Electrolyte number & 1 & 2 & 3 & 4 \\
\hline \multirow{2}{*}{ Electrolyte } & $\mathrm{K}_{4} \mathrm{P}_{2} \mathrm{O}_{7}$ & $\mathrm{~K}_{4} \mathrm{P}_{2} \mathrm{O}_{7}$ & $\mathrm{~K}_{4} \mathrm{P}_{2} \mathrm{O}_{7}$ & $\mathrm{~K}_{4} \mathrm{P}_{2} \mathrm{O}_{7}$ \\
components & $\mathrm{MoO}_{3}$ & $\mathrm{~V}_{2} \mathrm{O}_{5}$ & $\mathrm{ZrO}_{2}$ \\
& $\mathrm{Na}_{4} \mathrm{~B}_{4} \mathrm{O}_{7}$ & $\mathrm{Na}_{4} \mathrm{~B}_{4} \mathrm{O}_{7}$ & $\mathrm{Na}_{3} \mathrm{Cit}$ \\
\hline
\end{tabular}

This work presents certain results of investigation on the features of oxide coatings forming on the surface of titanium alloys using plasma-electrolytic oxidizing in alkali complex electrolytes containing oxides or oxoanions of doping metals and studying the composition and morphology of the synthesized mixed-oxide systems.

\section{Materials and Methods}

2.1. Materials. The formation of mixed-oxide systems $\mathrm{TiO}_{x} \cdot \mathrm{MO}_{y}(\mathrm{M}=\mathrm{Mo}, \mathrm{W}, \mathrm{V}$, and $\mathrm{Zr})$ was carried out on the titanium alloy VT1-0 by plasma-electrolytic oxidizing.

Electrochemical treatment performed in a thermostatic cell in aqueous electrolyte solutions based on pyrophosphates, borates, and acetates of alkali metals with the addition of dopants' oxides or oxoanions is shown in Table 1. Working solutions for the research were prepared using certified reagents of the grade "chemically pure" and distilled water.

A preliminary treatment of the specimens included the mechanical purification from process impurities, degreasing in $0.2-0.3 \mathrm{M} \mathrm{NaOH}$, etching in the mixture of $0.1-0.3 \mathrm{M} \mathrm{HF}$ and 0.3-0.9 $\mathrm{M} \mathrm{HNO}_{3}$, and the distilled water flushing.

2.2. Synthesis Methods. The oxidation was carried on in the galvanostatic mode using the stabilized DC source B5-50 (Ukraine). The process was carried out at current densities of $1.0-5.0 \mathrm{~A} / \mathrm{dm}^{2}$ and total voltage up to $250 \mathrm{~V}$ (Table 2) in a thermostatic cell with vigorous stirring of the electrolyte and flow-through circulation cooling. The processing time was 30-90 minutes.

2.3. Methods of the Study. The specimen surface was studied using the scanning electron microscope ZEISS EVO 40XVP. The surface pattern was obtained by recording secondary electrons and scanning the surface with the electron beam that enabled the investigation of surface morphology with a high resolution and contrast range. The images were processed using the SmartSEM software environment. Chemical composition of the surface was defined by the analysis of characteristic X-ray spectrum that was recorded by the INCA Energy 350 electron probe microanalysis integrated into the system of the SEM. The X-ray was excited by the radiation of specimens with the electron beam of $15 \mathrm{kV}$.

In addition, the element composition of coatings was defined using the X-ray fluorescent method and portable allpurpose commercial X-ray spectrometer "SPRUT"; a relative standard deviation was in the range of $10^{-3}$ to $10^{-2}$.

The surface roughness of coatings was defined using the contact method and the scanning probe microscope AFM
TABLE 2: PEO parameters.

\begin{tabular}{lcccc}
\hline Electrolyte number & 1 & 2 & 3 & 4 \\
\hline $\begin{array}{l}\text { Current density, } \\
i\left(\mathrm{~A} / \mathrm{dm}^{2}\right)\end{array}$ & & \multicolumn{2}{c}{$1.0-5.0$} & \\
Sparking voltage, & $90-110$ & $100-120$ & $140-160$ & $110-120$ \\
$U_{\mathrm{s}}(\mathrm{V})$ & & & & \\
$\begin{array}{l}\text { Maximum voltage, } \\
U_{\max }(\mathrm{V})\end{array}$ & $180-190$ & $190-200$ & $210-220$ & $230-240$ \\
\hline
\end{tabular}

NT-206 (Microtestmashine Co, the Republic of Belarus). The specimens were scanned using the CSC-37 probe (cantilever $\mathrm{B}$, the lateral resolution of $3 \mathrm{~nm}$ ) at least at the three points on the surface in different sections of the sample for data averaging. A size of crystallite grains and a level of the roughness of surface coatings were defined using the obtained $2 \mathrm{D}$ and $3 \mathrm{D}$ surface charts and the cross section of the surface.

A corrosion behavior of the titanium alloys with oxide coatings was studied by the electrode impedance spectroscopy method using the automatic AC bridge P-5083 at the fixed frequencies of 1 and $10 \mathrm{kHz}$ and in the frequency range of $20-1 \cdot 10^{5} \mathrm{~Hz}$ [19] in the solution of $0.1 \mathrm{M} \mathrm{NaCl}$. The measurements taken in compliance with the series circuit were realized using auxiliary electrodes, in particular a coaxially arranged platinum grid or coplanar plates made of stainless steel.

The catalytic activity of conversion coatings on titanium was determined in the model photodestruction reaction of methyl orange dye $\mathrm{MO}$ in a thermostatic reactor at a temperature of $25^{\circ} \mathrm{C}$ and constant mixing. The reactor was filled with a solution with a dye concentration of $2 \times 10^{-2} \mathrm{~g} / \mathrm{dm}^{3}$, and the catalyst was placed and then kept in the dark for 24 hours to establish adsorption equilibrium. The irradiation was carried out with a fluorescent lamp of DeLux EBT-01, giving a soft ultraviolet, and oxygen or hydrogen peroxide was used as an oxidizing agent. The MO concentration was determined at the same intervals by the calorimetric method. The processing of the measurement results and the determination of the degree of photodegradation, as well as the apparent reaction rate constant $\mathrm{k}^{\prime}$, were carried out according to the developed algorithm [20].

\section{Results and Discussion}

Previous studies have shown that obtaining oxide-metallic coatings with a high-content of dopants was possible in the process of one-stage plasma-electrolytic oxidation of titanium $[12,21]$ and aluminum alloys [22] when using complex electrolytes.

The synthesized oxide materials did not require further treatment and possessed a broad range of functional properties, including catalytic activity in heterogeneous redox reactions. This approach to catalytic coating formation on the titanium alloy surface underlies the present research as a working hypothesis.

It was established that voltage chronograms (Figure 1) in studied electrolytes (Table 2) have a similar form, but they differ somewhat from the classical one [17]. The growth of 


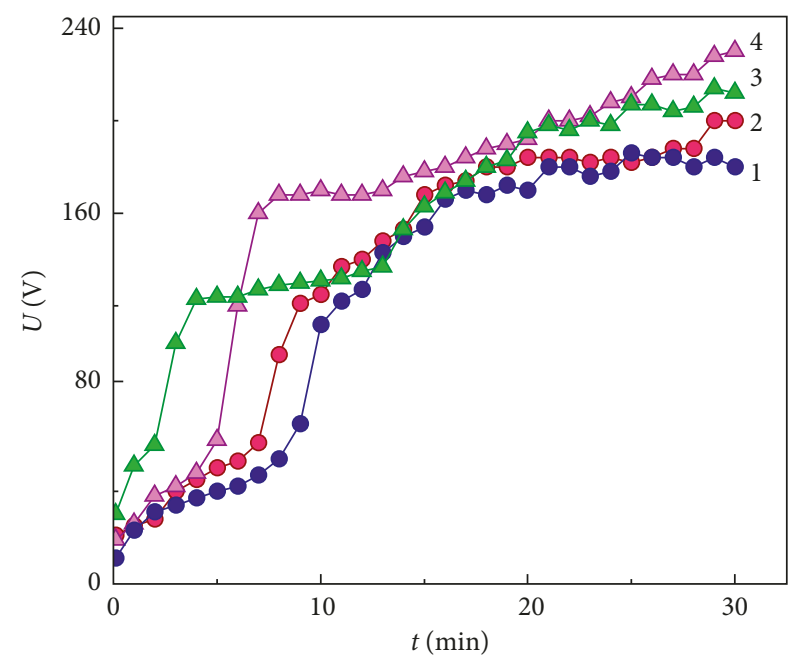

FIGURE 1: Chronograms of the forming voltage at $\mathrm{PEO}$ with current density $2 \mathrm{~A} / \mathrm{dm}^{2}$ for oxide coatings. 1 : $\mathrm{TiO}_{x} \cdot \mathrm{MoO}_{y} ; 2: \mathrm{TiO}_{x} \cdot \mathrm{V}_{2} \mathrm{O}_{5} ; 3$ : $\mathrm{TiO}_{x} \cdot \mathrm{WO}_{y} ; 4: \mathrm{TiO}_{x} \cdot \mathrm{ZrO}_{2}$.

the forming voltage at the initial stage of the process is extremely slow. On the voltage chronograms, a gently sloping plot is observed. Obviously, such characters of $U, t$ dependencies is associated with the competition of the direct process of phase titanium oxide formation and reverse one-its chemical dissolution. Upon reaching a voltage of 50-55 V, all dependences exhibit a sharp almost linear rise, corresponding to the formation of an oxide layer.

The voltage growth again significantly slows with the onset of film breakdown, and on the $U, t$ dependencies, we can see plateaus. It should be noted that both the level of first-limiting voltage $U_{1}$ and time interval for its stabilization depend on the nature of the dopant. Obviously, reactions of coating defects formation and healing, as well as electrolyte components incorporation in the oxide layer, balance on these plateau sites of dependences. The voltage $U_{1}$ for the systems $\mathrm{TiO}_{x} \cdot(\mathrm{Mo} \mathrm{V} \mathrm{W}) \mathrm{O}_{y}$ is at the level $110-120 \mathrm{~V}$ and for $\mathrm{TiO}_{x} \cdot \mathrm{ZrO}_{2}$ is higher- $160 \mathrm{~V}$.

The microarc region is characterized by a considerable number of oscillations with a general trend of increasing the voltage to $200-220 \mathrm{~V}$. This is obviously due to the active inclusion of electrolyte components in the coating composition, which forms compounds with different oxidation degrees and, accordingly, different resistivity, and thermal stability (Table 3 ).

For all oxide coatings, the dependences of the voltage change rate are similar in shape (Figure 2). In the prespark area, they are characterized by a slight decrease with a minimum in the range of $45-50 \mathrm{~V}$. It is related to the balancing of the processes of formation and dissolution of titania [12].

With an increase in voltage, there is a rapid increase in the rate of voltage change, reflecting the predominance of the oxide layer formation and growth over its dissolution. A further decrease in $\mathrm{d} U / \mathrm{d} t$ is evidently a consequence of the breakdown of the oxide film, as well as of the accompanying processes of electrolyte components incorporation and their high-temperature transformations in the sparking zone.
TABLE 3: Specific electrical resistance and thermal stability of oxides [23].

\begin{tabular}{|c|c|c|c|}
\hline Metal & Oxide & $\begin{array}{c}\text { Specific electrical } \\
\text { resistance } \rho(\Omega \cdot \mathrm{cm}) \text { at } \\
293 \mathrm{~K}\end{array}$ & $\begin{array}{l}\text { Thermal } \\
\text { stability }\end{array}$ \\
\hline \multirow[t]{2}{*}{ Mo } & $\mathrm{MoO}_{2}$ & $\begin{array}{c}8.8 \cdot 10^{-5} \text { metallic } \\
\text { conductivity }\end{array}$ & $\begin{aligned} T & >2100 \\
3 \mathrm{MoO}_{2} & \rightarrow \mathrm{Mo}+2 \mathrm{MoO}_{3}\end{aligned}$ \\
\hline & $\mathrm{MoO}_{3}$ & $10^{4}-10^{8}$ semiconductor & $-1-$ \\
\hline \multirow{3}{*}{ W } & $\mathrm{WO}_{2}$ & $\begin{array}{l}3 \cdot 10^{-3} p \text {-type } \\
\text { semiconductor }\end{array}$ & $\begin{aligned} T & >2150 \\
3 \mathrm{WO}_{2} & \rightarrow \mathrm{W}+2 \mathrm{WO}_{3}\end{aligned}$ \\
\hline & $\mathrm{WO}_{3}$ & $10^{3}-10^{5}$ & At a temperature above \\
\hline & $N_{3}$ & semiconductor & $1098 \mathrm{~K}$ sublimes \\
\hline \multirow[b]{2}{*}{ V } & $\mathrm{VO}_{2}$ & $\begin{array}{l}8 \cdot 10^{-4} n \text {-type } \\
\text { semiconductor }\end{array}$ & - \\
\hline & $\mathrm{V}_{2} \mathrm{O}_{5}$ & $\begin{array}{l}4 \cdot 10^{-3} n \text {-type } \\
\text { semiconductor }\end{array}$ & $\begin{array}{c}1000-1550 \mathrm{~K} \\
2 \mathrm{~V}_{2} \mathrm{O}_{5} \rightarrow 4 \mathrm{VO}_{2}+\mathrm{O}_{2} \\
\left(\mathrm{~V}_{6} \mathrm{O}_{13}\right)\end{array}$ \\
\hline $\mathrm{Zr}$ & $\mathrm{ZrO}_{2}$ & $10^{13}$ dielectric & - \\
\hline
\end{tabular}

At the same time, the microarc region is characterized by process instability and the appearance of $\mathrm{d} U / \mathrm{d} t$ oscillations. It is associated with competition and a stochastic distribution of processes breakdown, healing for a complex oxide system.

The data of micro-X-ray spectral analysis and the scanning electron microscopy show inclusion of electrolyte components remelt into $\mathrm{TiO}_{2}$ coatings. The surface morphology strongly depends on the content of alloying elements in mixed-oxide coatings. Figure 3 depends to a larger extent on the nature of the dopant compound. Uniform lowporosity oxide coatings with a doping component content $\omega$ of (\% by weight) Mo: 3.0, V: 4.0, and Zr: 4.0 were formed in solutions based on dispersed metal oxides.

Analysis of the topography and components surface distribution for coatings $\mathrm{TiO}_{x} \cdot \mathrm{WO}_{y}$ obtained by $\mathrm{PEO}$ in electrolyte solutions based on tungstate of different concentrations allows us to conclude, that picks of the clusters are enriched in tungsten (Figure 4(a)), and the valleys matrix is characterized by maximal content of titanium (Figure 4(b)). The coatings have a tubular microporous structure, a characteristic of titanium nanotubes, and the surface is covered with toroidal rings.

It should be noted that varying the concentration of sodium tungstate in solution and increasing the current density make it possible to obtain coatings of different dopant contents, which also differ in relief (Figure 5).

With the increase in the tungsten content in the coating, large clusters disappear, and a more perfect microglobular structure with rounded grains of similar diameter (up to $1 \mu \mathrm{m})$, as well as toroidal structures, are formed. When the content of tungsten in oxides is increased by more than $50 \%$ by weight (10 at.\%) (Figure 6(a)), the surface is covered by a network of microcracks due to high internal stresses associated with the concentration of the refractory metal and with high applied current density (Figure 6(b)).

Proceeding from the specifics of the synthesized materials application as catalytically active components of the complex systems at elevated temperatures and the effect of various fields, analysis of the composition and morphology 


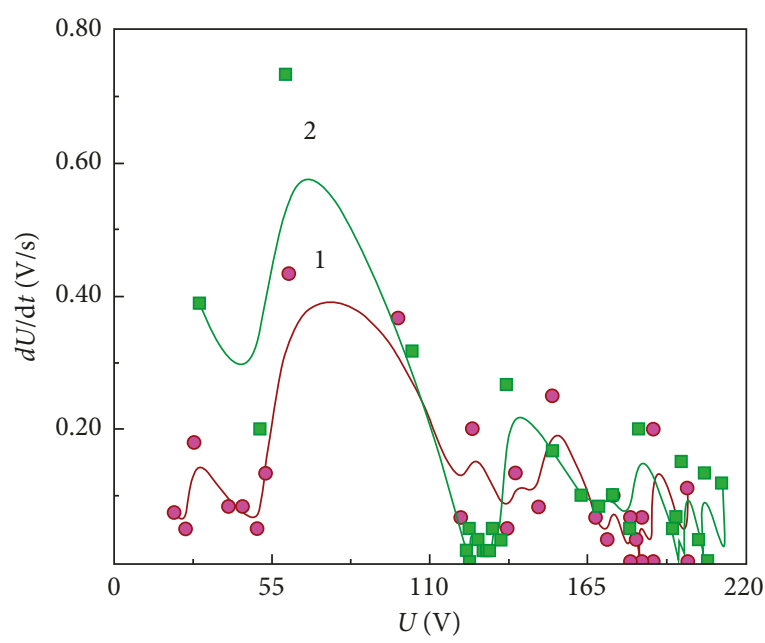

(a)

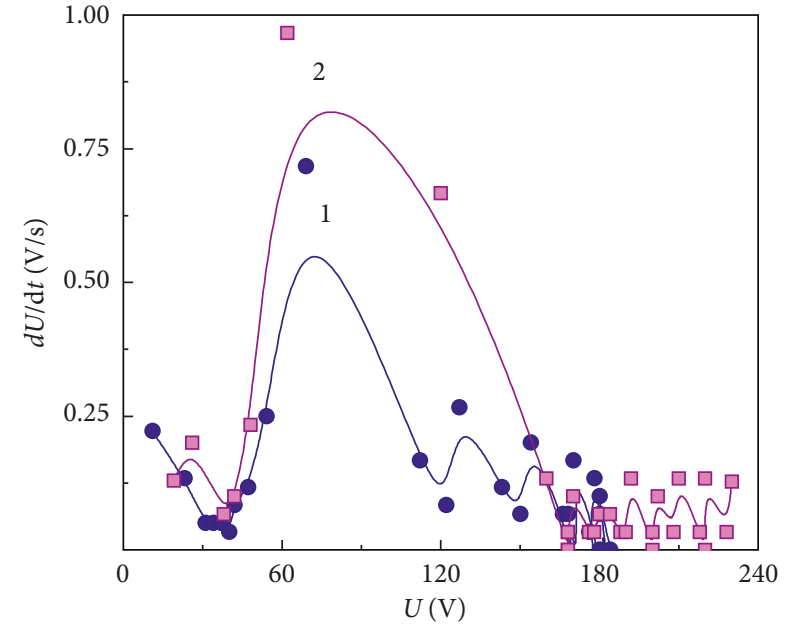

(b)

Figure 2: Rate of voltage change when forming coatings: (a) $1: \mathrm{TiO}_{x} \cdot \mathrm{V}_{2} \mathrm{O}_{5} ; 2: \mathrm{TiO}_{x} \cdot \mathrm{WO}_{y}$ (b) $1: \mathrm{TiO}_{x} \cdot \mathrm{MoO}_{y} ; 2: \mathrm{TiO}_{x} \cdot \mathrm{ZrO}_{2}$.
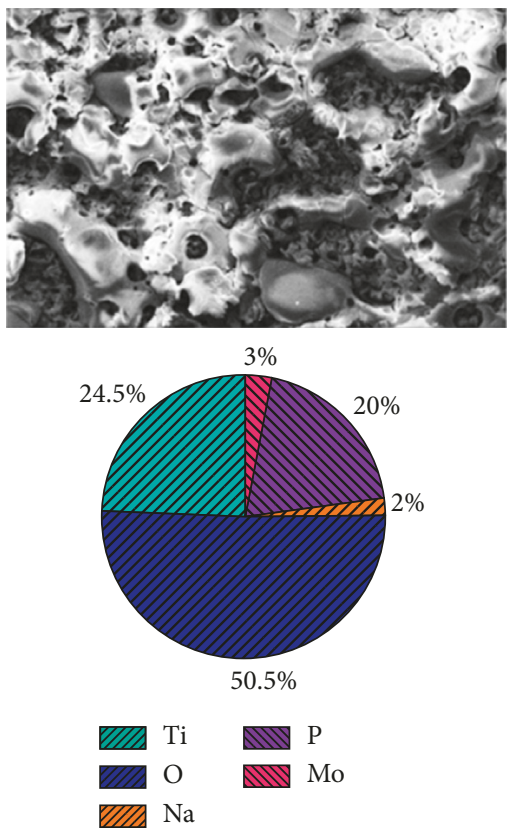

(a)

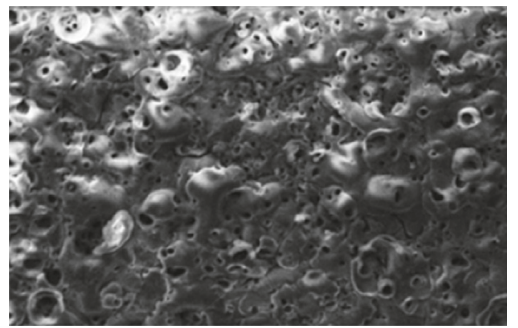

$4.3 \%$
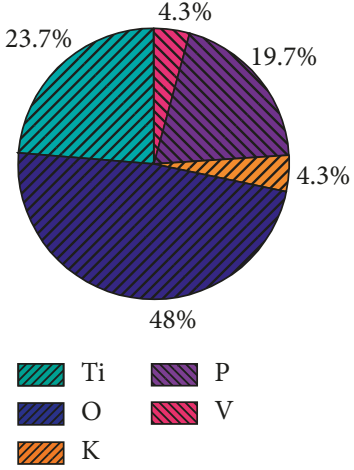

(b)
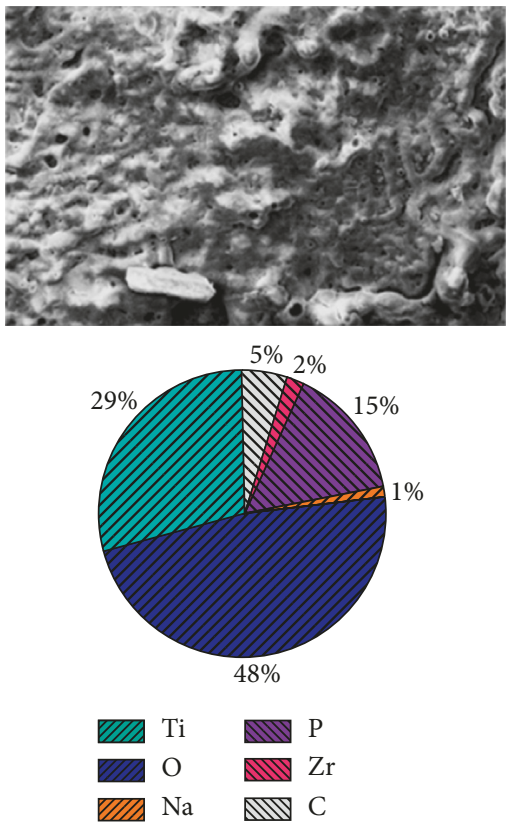

(c)

Figure 3: Surface microphotographs (magnification $\times 500)$ and composition (\% by weight) of mixed- $\mathrm{PEO}$ coatings: $(\mathrm{a}) \mathrm{TiO}_{x} \cdot \mathrm{MoO}_{y}$; (b) $\mathrm{TiO}_{x} \cdot \mathrm{V}_{2} \mathrm{O}_{5}$; (c) $\mathrm{TiO}_{x} \cdot \mathrm{ZrO}_{2}$.

of the surface after thermal treatment at $450^{\circ} \mathrm{C}$ for 6 hours was very informative. As seen from Figure 7, heat treatment leads to the enlargement of the grains dimensions and an increase in the surface roughness, as well as a decrease in the oxygen content.

So, the quantitative composition of the coatings, as well as the surface cluster nature, creates the prerequisites for high catalytic activity of mixed oxides [24], which can be increased by additional heat treatment.

The roughness is an indicator of surface quality and depends on the material processing method. So, it can be regarded as an additional indicator of the surface development during oxidation [21, 25]. Estimating the topography of the titanium alloy VT1-0 surface oxidized in potassium diphosphate, we can conclude the coatings to be unevenly rough (Figure 8).

Analysis of the cross section of grain between markers 1 and 2 (Figure $8(\mathrm{~b})$ ) indicates that the grain size varies between 400 and $500 \mathrm{~nm}$, and the height of the parabolic picks of the relief is $100-400 \mathrm{~nm}$ (Figure $8(\mathrm{c})$ ).

The topography of the $\mathrm{TiO}_{2} \cdot \mathrm{ZrO}_{2}$ system surface (Figure 9(a)) differs significantly from the previous one: it has a fine-crystalline structure with the maximum degree of development in the series of materials considered. 


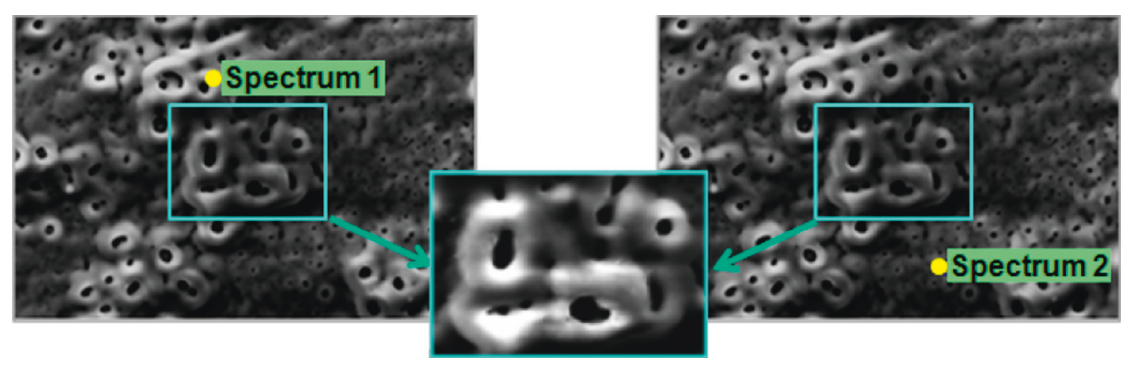

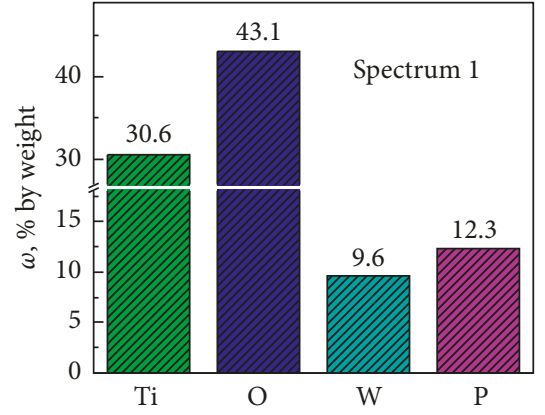

(a)

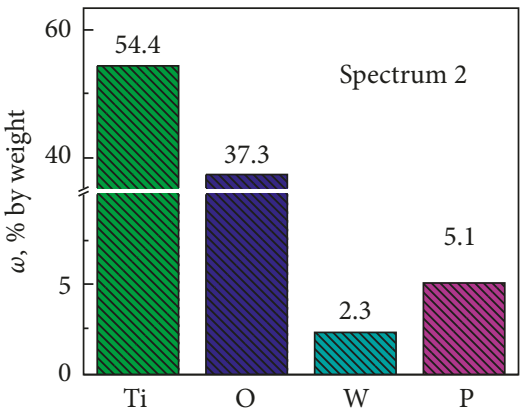

(b)

Figure 4: Surface morphology $(\times 2000)$ and the elemental composition of $\mathrm{TiO}_{x} \cdot \mathrm{WO}_{y}$ oxide coatings: (a) at picks of clusters; (b) at valleys.

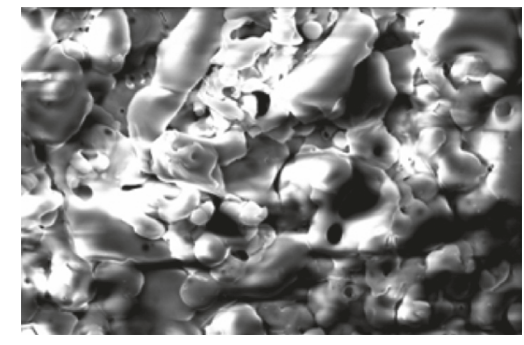

$\mathrm{Ti}-29.5 ; \mathrm{W}-5.7$

(a)

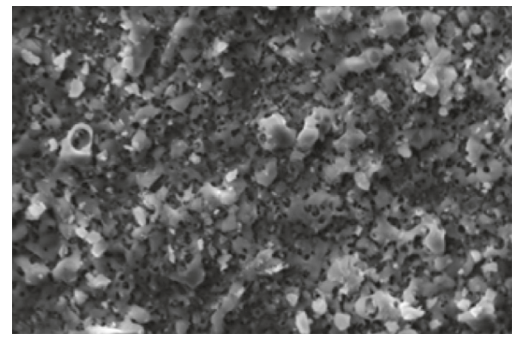

$\mathrm{Ti}-39.6 ; \mathrm{W}-13.7$

(b)

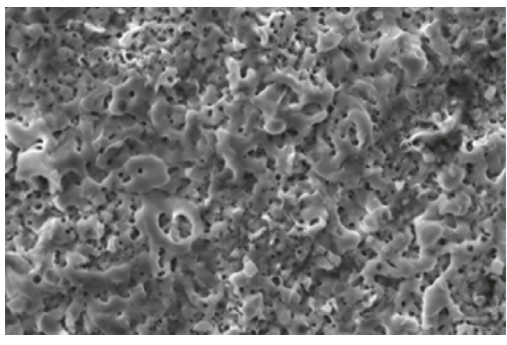

$\mathrm{Ti}-22.8 ; \mathrm{W}-44.5$

(c)

Figure 5: Surface morphology and the elemental composition (\% by weight) of the $\mathrm{TiO}_{x} \cdot \mathrm{WO}_{y}$ oxide PEO coatings, obtained at different current densities $\left(i, \mathrm{~A} / \mathrm{dm}^{2}\right)$ : (a) 1.5 ; (b) 2.5 ; (c) 4.0. Magnification $\times 2000$.

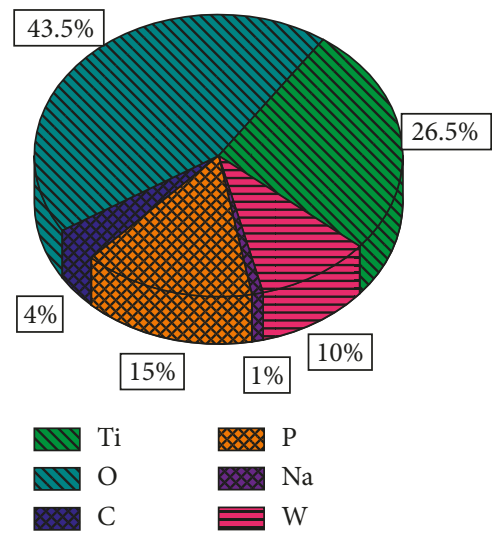

(a)

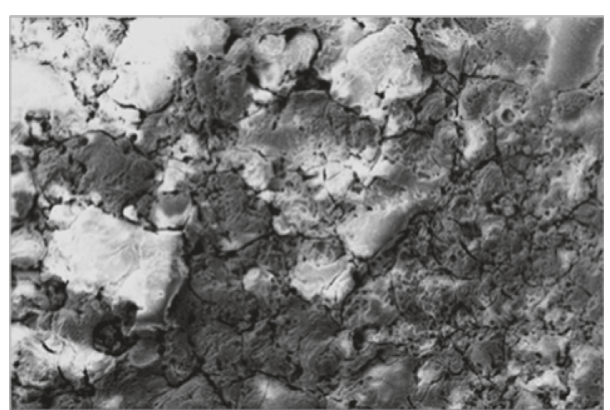

(b)

FIgURE 6: Oxide coatings $\mathrm{TiO}_{x} \cdot \mathrm{WO}_{y}$, obtained at $i=5.0 \mathrm{~A} / \mathrm{dm}^{2}$ : (a) elemental composition, at.\%; (b) surface morphology. Magnification $\times 200$. 

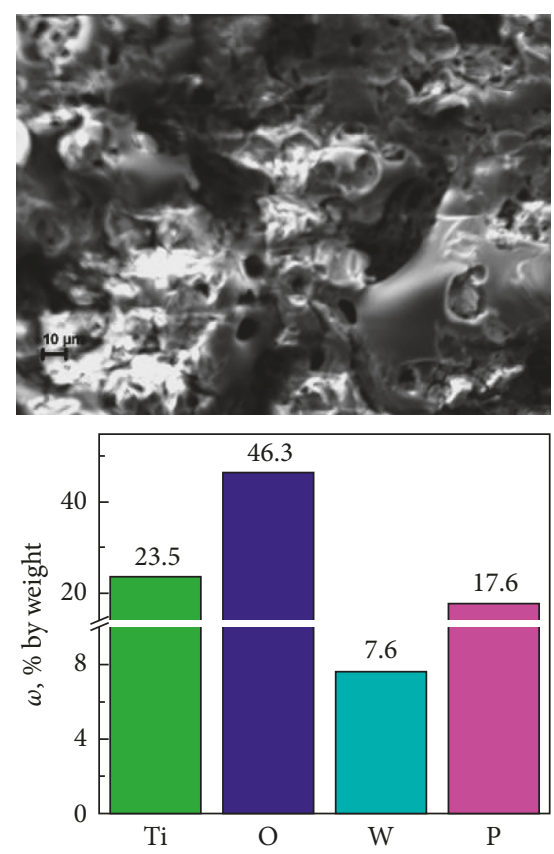

(a)
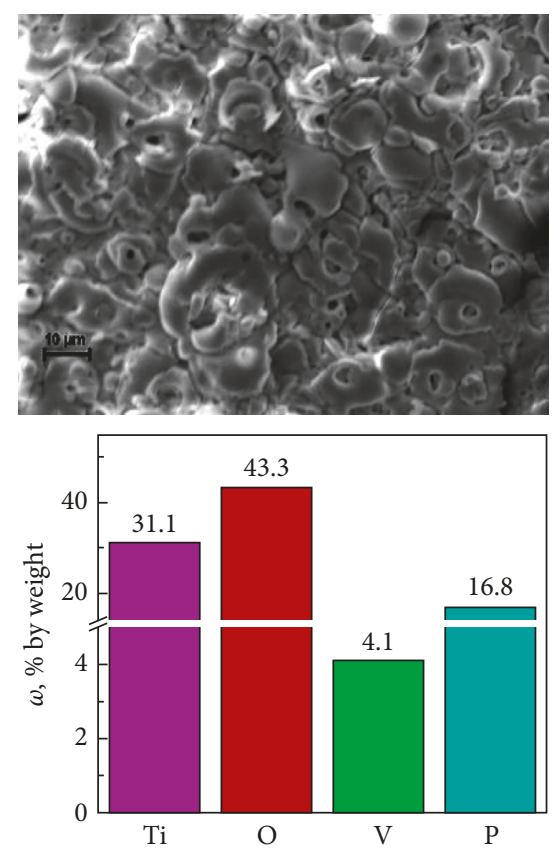

(b)
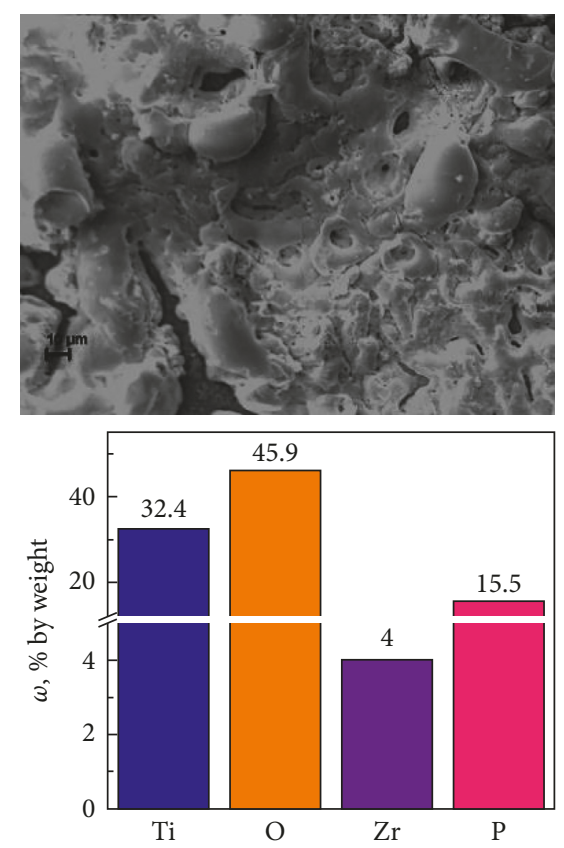

(c)

Figure 7: Surface morphology and elemental composition of mixed-oxide coatings $\mathrm{TiO}_{x} \cdot \mathrm{MO}_{y}$ after heat treatment: (a) TiO $x$. WO (b) $\mathrm{TiO}_{x} \cdot \mathrm{VO}_{y}$; (c) $\mathrm{TiO}_{x} \cdot \mathrm{ZrO}_{y}$. Magnification $\times 500$.

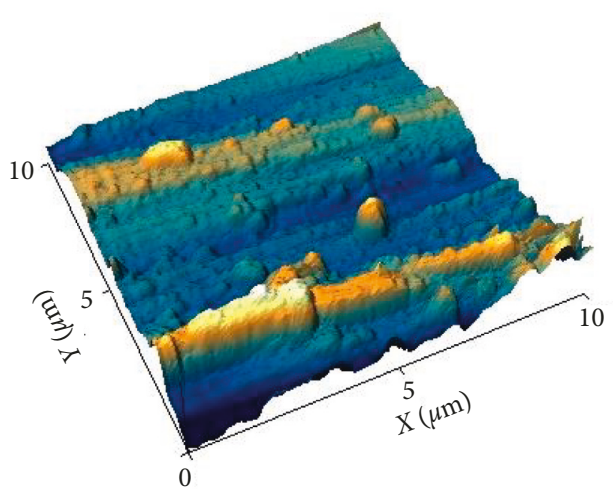

(a)

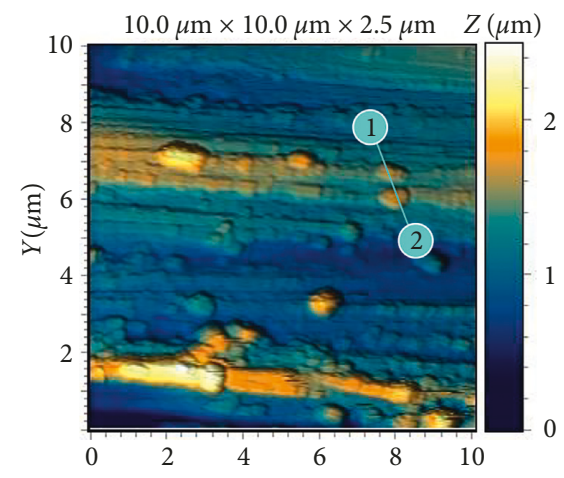

(b)

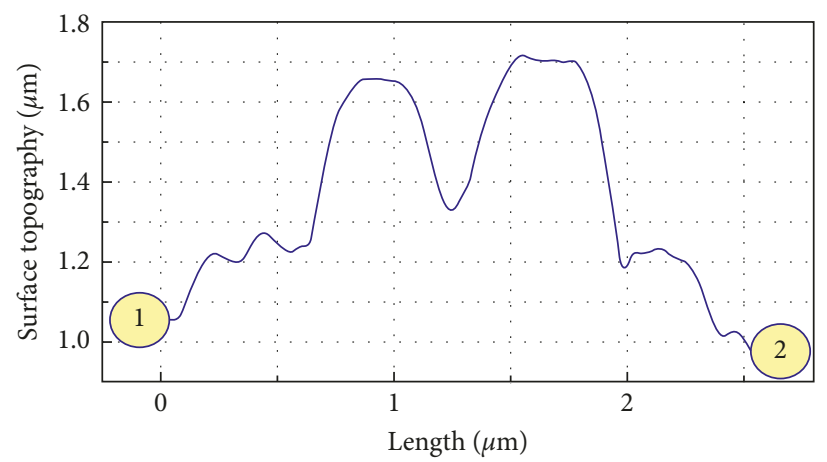

(c)

FIGURE 8: 3D (a) and 2D maps (b) of the surface and cross-sectional profile between markers 1 and 2 (c) for Ti $\mid \mathrm{TiO}_{2}$ coating, obtained from $1 \mathrm{M} \mathrm{K}_{4} \mathrm{P}_{2} \mathrm{O}_{7}, i=1.5 \mathrm{~A} / \mathrm{dm}^{2}, U=60 \mathrm{~V}, t=25^{\circ} \mathrm{C}$. Scanning area AFM $10 \times 10 \mu \mathrm{m}$. 


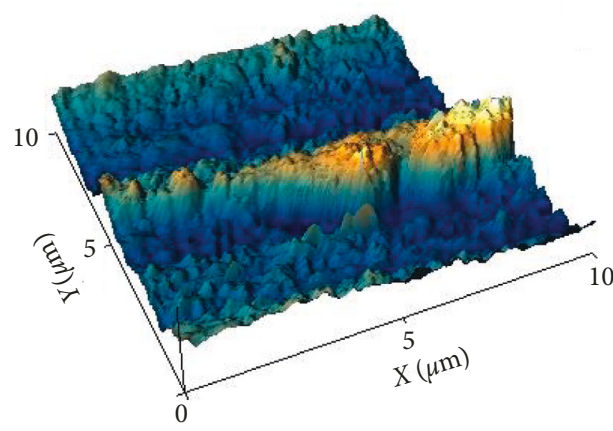

(a)

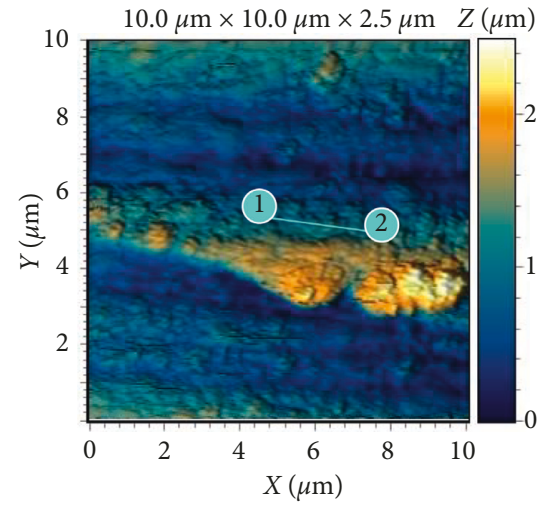

(b)

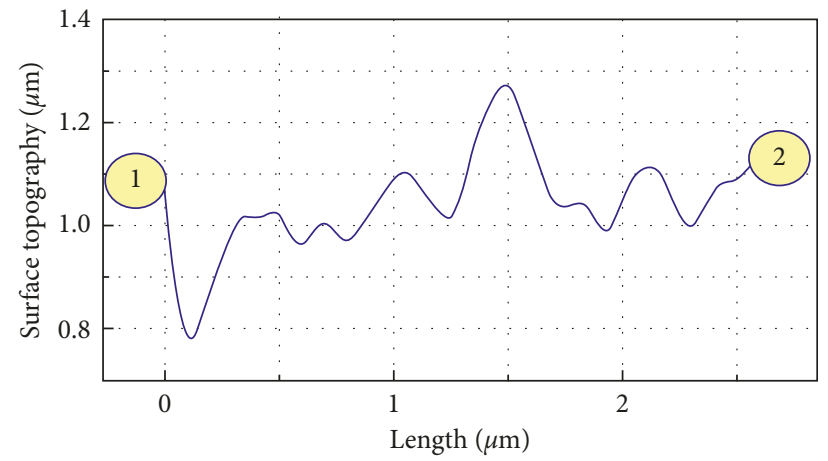

(c)

FigURE 9: 3D (a) and 2D maps (b) of the surface and cross-sectional profile between markers 1 and 2 (c) for coating $\mathrm{Ti} \mid \mathrm{TiO}_{2} \cdot \mathrm{ZrO}_{2}$. Scanning area AFM $10 \times 10 \mu \mathrm{m}$. Content of $\mathrm{Zr} 2.1 \%$ by weight.

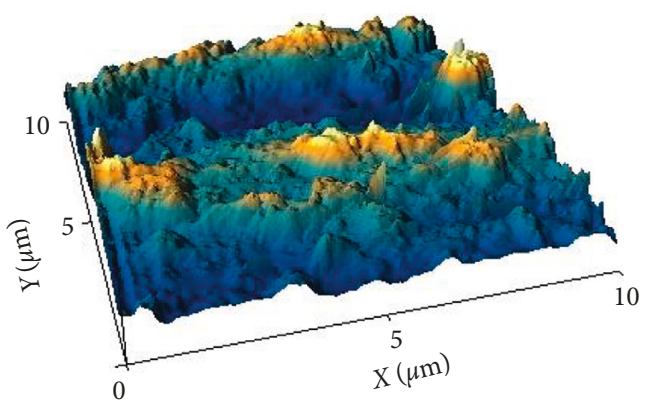

(a)

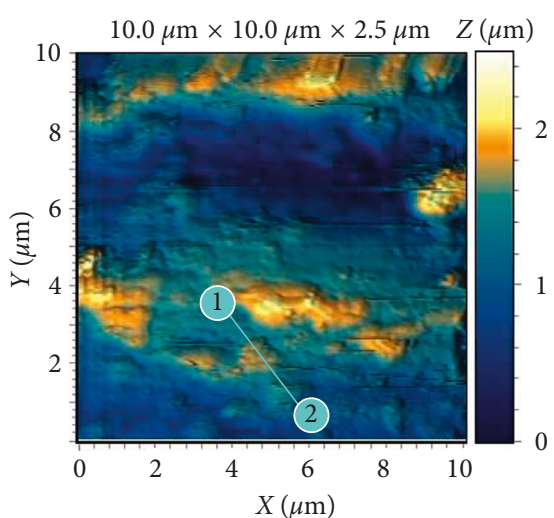

(b)

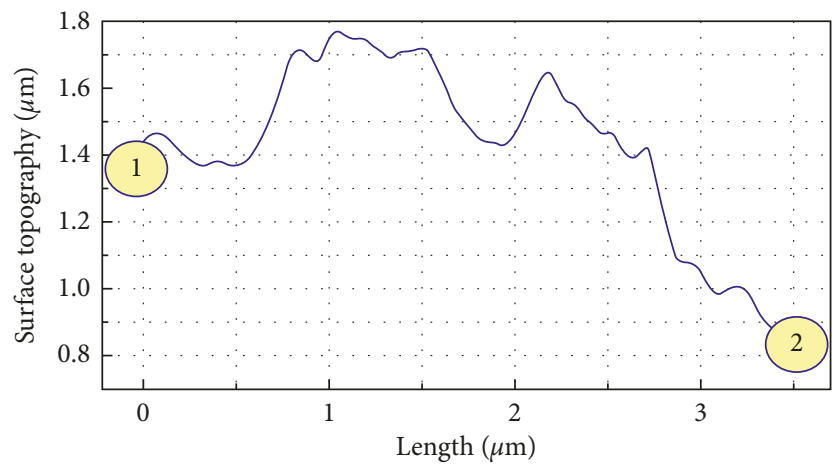

(c)

Figure 10: 3D (a) and 2D maps (b) of the surface and cross-sectional profile between markers 1 and 2 (c) for Ti $\mid \mathrm{TiO}_{2} \cdot \mathrm{ZrO}_{2}$ coating after calcination. Scanning area AFM $10 \times 10 \mu \mathrm{m}$. Content of $\mathrm{Zr} 2.1 \%$ by weight. 


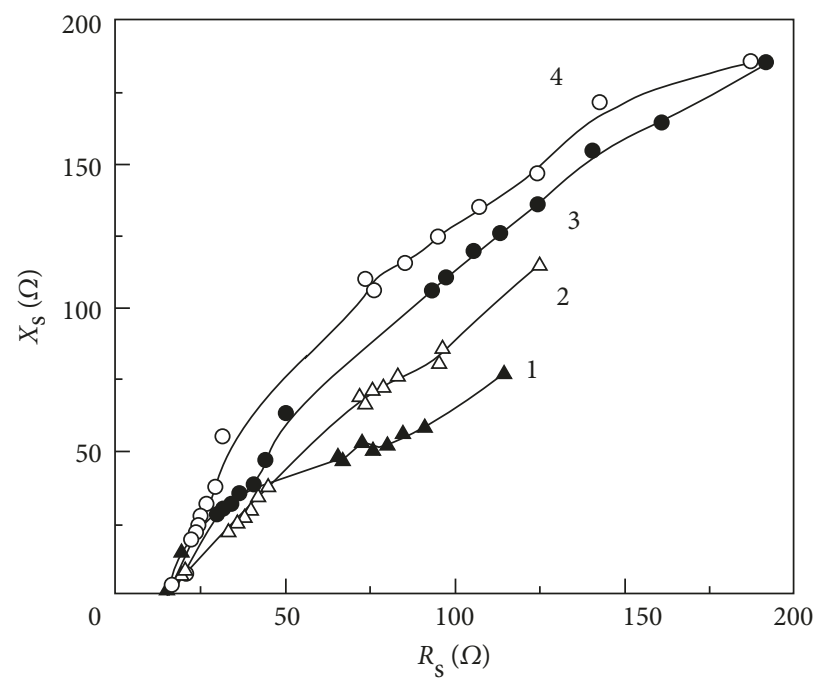

(a)

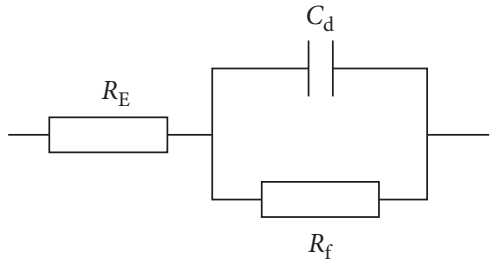

(b)

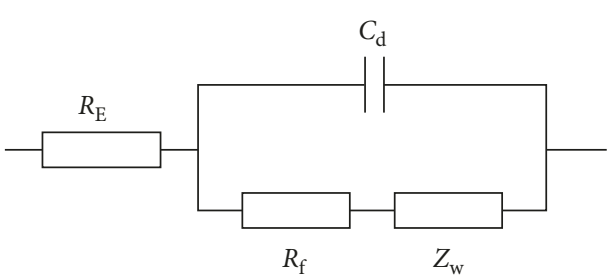

(c)

Figure 11: Nyquist plots (a) of mixed-oxide systems: $1: \mathrm{TiO}_{x} \cdot \mathrm{WO}_{y} ; 2: \mathrm{TiO}_{x} \cdot \mathrm{MoO}_{y} ; 3: \mathrm{TiO}_{x} \cdot \mathrm{V}_{2} \mathrm{O}_{5} ; 4: \mathrm{TiO}_{x} \cdot \mathrm{ZrO}_{2}$ and the corresponding equivalent substitution schemes for systems $\mathrm{TiO}_{x} \cdot \mathrm{WO}_{y}$ and $\mathrm{TiO}_{x} \cdot \mathrm{MoO}_{y}(\mathrm{~b})$ and $\mathrm{TiO}_{y} \cdot \mathrm{V}_{2} \mathrm{O}_{5}$ and $\mathrm{TiO}_{x} \cdot \mathrm{ZrO}_{2}$ (c).

The spread in the sizes of grains agglomerates is $150-300 \mathrm{~nm}$ and varies in height from 100 to $500 \mathrm{~nm}$ (Figure 9(b)). The cross-sectional profile of the $\mathrm{TiO}_{2} \cdot \mathrm{ZrO}_{2}$ between markers $1-2$ is characterized by a variety of grain shapes with a predominance of pointed crystals (Figure $9(c))$. Heat treatment of mixed-oxide coatings also changes the topography of the surface (Figures 10(a) and 10(b)). The relief acquires a globular shape and becomes more uniform, the agglomerates sizes are reduced to 140 $200 \mathrm{~nm}$, and the grain sizes remain within $80-100 \mathrm{~nm}$ (Figure 10(c)). The spread of the picks and valleys along the height also decreases in comparison with the unheated material. The uniformly developed surface is one of the factors ensuring an increase in the catalytic activity of the oxide system after calcinations.

Thus, doping of titania with zirconium oxides leads to a change in the morphology of the surface and an increase in its specific area. Thermal treatment of mixed-oxide systems helps to reduce the size of agglomerates and grains and provides a uniformly developed surface. The combination of these factors is the methodological basis for increasing the catalytic activity of materials, especially in the application to photocatalysis $[5,10]$.

Corrosion tests were carried out for mixed systems $\mathrm{TiO}_{x} \cdot \mathrm{V}_{2} \mathrm{O}_{5}$ and $\mathrm{TiO}_{x} \cdot \mathrm{ZrO}_{2}$. Nyquist plots constructed from the results of electrode impedance measurements (Figure 11, curves 3,4$)$ are fragments of semicircles, reflecting the kinetic control of the corrosion process.
TABLE 4: Corrosion parameters of samples with coatings: $\mathrm{TiO}_{x}$ oxides of metals in solution $0.1 \mathrm{M} \mathrm{NaCl}$.

\begin{tabular}{|c|c|c|c|}
\hline \multirow[b]{2}{*}{ Coating } & \multicolumn{2}{|c|}{ Corrosion rate } & \multirow[b]{2}{*}{$\begin{array}{c}\text { Open circut } \\
\text { potential, } E_{\text {cor }}(\mathrm{V})\end{array}$} \\
\hline & $\begin{array}{l}i_{\text {cor }} \cdot 10^{6} \\
\left(\mathrm{~A} / \mathrm{cm}^{2}\right)\end{array}$ & $\begin{array}{c}k_{\mathrm{h}} \cdot 10^{4} \\
(\mathrm{~mm} / \text { year })\end{array}$ & \\
\hline$\overline{\mathrm{TiO}_{x} \cdot \mathrm{WO}_{y}}$ & 1.509 & 1.97 & -0.17 \\
\hline $\mathrm{TiO}_{x} \cdot \mathrm{MoO}_{y}$ & 0.755 & 0.98 & -0.122 \\
\hline $\mathrm{TiO}_{x} \cdot \mathrm{V}_{2} \mathrm{O}_{5}$ & 0.377 & 0.49 & -0.104 \\
\hline $\mathrm{TiO}_{x} \cdot \mathrm{ZrO}_{2}$ & 0.279 & 0.36 & -0.08 \\
\hline
\end{tabular}

TABLE 5: Characteristics of the photocatalytic activity of oxide systems obtained at $i=1.5 \mathrm{~A} / \mathrm{dm}^{2}$.

\begin{tabular}{lccc}
\hline $\begin{array}{l}\text { Coating } \\
\text { composition }\end{array}$ & Electrolyte & $\begin{array}{c}\text { Degree of } \\
\text { destruction } \\
(\%)\end{array}$ & $\begin{array}{c}k^{\prime} \cdot 10^{2} \\
\left(\mathrm{~min}^{-1}\right)\end{array}$ \\
\hline $\mathrm{Ti} \mid \mathrm{TiO}_{2}$ & $0.5 \mathrm{M} \mathrm{H}_{2} \mathrm{SO}_{4}$ & 28.00 & 0.88 \\
$\mathrm{Zr} \mid \mathrm{ZrO}_{2}$ & $1 \mathrm{M} \mathrm{K}_{4} \mathrm{P}_{2} \mathrm{O}_{7}$ & 24.10 & 0.8 \\
& $0.5 \mathrm{M} \mathrm{H}_{2} \mathrm{SO}_{4} ; 0.1 \mathrm{M} \mathrm{ZrO}_{2}$ & 59.00 & 0.66 \\
$\mathrm{Ti} \mid \mathrm{TiO}_{x} \cdot \mathrm{ZrO}_{2}$ & $1 \mathrm{M} \mathrm{K}_{4} \mathrm{P}_{2} \mathrm{O}_{7} ; 0.1 \mathrm{M} \mathrm{ZrO}_{2}$ & 53.92 & 1.69 \\
$\mathrm{Ti} \mid \mathrm{TiO}_{x} \cdot \mathrm{V}_{2} \mathrm{O}_{5}$ & $1 \mathrm{M} \mathrm{K}_{4} \mathrm{P}_{2} \mathrm{O}_{7} ; 0.1 \mathrm{M} \mathrm{V} \mathrm{O}_{5}$ & 68.90 & 1.89 \\
\hline
\end{tabular}

The impedance plots of the samples with $\mathrm{TiO}_{x} \cdot \mathrm{WO}_{y}$ and $\mathrm{TiO}_{x} \cdot \mathrm{MoO}_{y}$ coatings containing metal oxides in the intermediate oxidation state (Figure 11(a), curves 1 and 2, resp.) consist of two sections: a semicircular fragment and 
a straight line with an inclination angle close to $45^{\circ}$. This form of dependence indicates a mixed diffusion-kinetic control of the corrosion process.

In Figures 11(b) and 11(c), equivalent substitution schemes for the considered mixed-oxide systems are presented. Scheme (Figure 11(b)) includes elements such as $R_{\mathrm{E}}$, electrolyte resistance, and parameters of Faraday reactions on the other surface parts are visualized by the elements $C_{\mathrm{d}}$ and $R_{\mathrm{f}}$. The other scheme (Figure 11(c)) differs by diffusion Warburg impedance $Z_{\mathrm{W}}$. The values of the current $i_{\text {cor }}$ and depth $k_{\mathrm{h}}$ of the corrosion rate indicators, as well as the corrosion potential of $E_{\text {cor }}$ indicate a sufficiently high-corrosion resistance of the systems under study and allow the materials to be classified as very stable (Table 4 ). The coatings containing zirconium oxide have the highest protective properties. The results obtained are quite natural, since it is zirconium oxide which increases the resistance to pitting corrosion.

Thus, the method of plasma-electrolytic oxidizing of titanium allows synthesizing mixed coatings containing dopedmetals oxides, differing in composition, porosity, surface roughness, and corrosion resistance in aggressive media [26].

Tests of the catalytic activity of mixed-oxide systems show that the $\mathrm{MO}$ dye oxidation rate and degree of photodestruction at $\mathrm{Ti} \mid \mathrm{TiO}_{2} \cdot \mathrm{ZrO}_{2}$ catalyst increases by $10 \%$ and at $\mathrm{Ti} \mid \mathrm{TiO}_{2} \cdot \mathrm{V}_{2} \mathrm{O}_{5}$ by $30 \%$ relative to the pure titania coatings (Table 5) [26].

\section{Conclusions}

(1) The method of plasma-electrolytic oxidizing allows synthesizing uniform microporous conversion and composite coatings with a developed surface containing mixed-oxide systems $\mathrm{TiO}_{x}$ with $\mathrm{WO}_{y}, \mathrm{MoO}_{y}$, $\mathrm{ZrO}_{2}$, and $\mathrm{V}_{2} \mathrm{O}_{5}$. A distinctive feature of the synthesis in its technical implementation is the variability, due to the possibility of forming such coatings in electrolytes both on the basis of dopant oxoanions and their dispersed oxides.

(2) The influence of electrolyte nature and PEO parameters on the mixed-oxide composition, surface morphology and roughness, and consequently, functional properties is shown.

(3) Corrosion resistance of oxide systems increase in the range $\mathrm{TiO}_{x} \cdot \mathrm{ZrO}_{2}>\mathrm{TiO}_{x} \cdot \mathrm{V}_{2} \mathrm{O}_{5}>\mathrm{TiO}_{x} \cdot \mathrm{MoO}_{y}>$ $\mathrm{TiO}_{x} \cdot \mathrm{WO}_{y}$.

(4) Analysis of the catalytic activity of mixed oxides and composite coatings in the model reaction of methyl orange oxidation showed not only their high efficiency but also the synergism. The established values of the quantitative characteristics of the photocatalytic degradation of a number of organic compounds provide grounds for asserting the prospects of using the systems studied to neutralize toxic reagents, in particular, such as formaldehyde, phenol, and their derivatives.

\section{Data Availability}

The data used to support the findings of this study are available from the corresponding author upon request.

\section{Conflicts of Interest}

The authors certify that they have no conflicts of interest.

\section{Acknowledgments}

The authors acknowledge the Karpenko Physico-Mechanical Institute of the NAS of Ukraine for providing all the support during the study period.

\section{References}

[1] S. L. Suib, New and Future Developments in Catalysis: Catalysis for Remediation and Environmental Concerns, Elsevier, New York, NY, USA, 2013.

[2] S. Bagheri, N. Muhd Julkapli, and S. Bee Abd Hamid, "Titanium dioxide as a catalyst support in heterogeneous catalysis," The Scientific World Journal, vol. 2014, Article ID 727496, 21 pages, 2014.

[3] A. Fujishima, K. Hashimoto, and T. Watanabe, $\mathrm{TiO}_{2}$ Photocatalysis: Fundamentals and Applications, BKC, Tokyo, Japan, 1999.

[4] L. Lin, Y. Chai, B. Zhao et al., "Photocatalytic oxidation for degradation of VOCs," Open Journal of Inorganic Chemistry, vol. 3, no. 1, pp. 14-25, 2013.

[5] V. S. Rudnev, I. V. Lukiyanchuk, M. S. Vasilyeva, M. A. Medkov, M. V. Adigamova, and V. I. Sergienko, "Aluminum- and titanium-supported plasma electrolytic multicomponent coatings with magnetic, catalytic, biocide or biocompatible properties," Surface and Coatings Technology, vol. 307, pp. 1219-1235, 2016.

[6] H. Liu, L. Yu, W. Chen, and Y. Li, "The progress of $\mathrm{TiO}_{2}$ nanocrystals doped with rare earth ions," Journal of Nanomaterials, vol. 2012, Article ID 235879, 9 pages, 2012.

[7] I. V. Lukiyanchuk, V. S. Rudnev, and L. M. Tyrina, "Plasma electrolytic oxide layers as promising systems for catalysis," Surface and Coatings Technology, vol. 307, pp. 1183-1193, 2016.

[8] X. H. Wu, Q. Wei, X. B. Ding, W. D. He, and Z. H. Jiang, "Dopant influence on the photo-catalytic activity of $\mathrm{TiO}_{2}$ films prepared by micro-plasma oxidation method," Journal of Molecular Catalysis A: Chemical, vol. 268, no. 1-2, pp. 257263, 2007.

[9] V.S. Rudnev, "Multiphase anodic layers and prospects of their application," Protection of Metals, vol. 44, no. 3, pp. 263-272, 2008.

[10] V. D. Binas, D. Kotzias, and G. Kiriakidis, "Modified $\mathrm{TiO}_{2}$ based photocatalysts for improved air and health quality," Journal of Materiomics, vol. 3, no. 1, pp. 3-16, 2017.

[11] M. S. Vasilyeva, V. S. Rudnev, A. Y. Ustinov, I. A. Korotenko, E. B. Modin, and O. V. Voitenko, "Cobalt-containing oxide layers on titanium, their composition, morphology, and catalytic activity in CO oxidation," Applied Surface Science, vol. 257, no. 4, pp. 1239-1246, 2010.

[12] L. Yan, T. Lihong, T. Xinyu, L. Xin, and C. Xiaobo, "Synthesis, properties, and applications of black titanium dioxide nanomaterials," Science Bulletin, vol. 62, no. 6, pp. 431-441, 2017.

[13] M. R. Bayati, R. Molaei, A. Z. Moshfegh, and F. GolestaniFard, "A strategy for single-step elaboration of $\mathrm{V}_{2} \mathrm{O}_{5}$-grafted $\mathrm{TiO}_{2}$ nanostructured photocatalysts with evenly distributed pores," Journal of Alloys and Compounds, vol. 509, no. 21, pp. 6236-6241, 2011. 
[14] S. Stojadinović, N. Radić, R. Vasilić et al., "Photocatalytic properties of $\mathrm{TiO}_{2} / \mathrm{WO}_{3}$ coatings formed by plasma electrolytic oxidation of titanium in 12-tungstosilicic acid," Applied Catalysis B: Environmental, vol. 126, pp. 334-341, 2012.

[15] S. Di, Y. Guo, H. Lv, J. Yu, and Z. Li, "Microstructure and properties of rare earth $\mathrm{CeO}_{2}$-doped $\mathrm{TiO}_{2}$ nanostructured composite coatings through micro-arc oxidation," Ceramics International, vol. 41, no. 5, pp. 6178-6186, 2015.

[16] M. Babaei, C. Dehghanian, P. Taheri, and M. Babaei, "Effect of duty cycle and electrolyte additive on photocatalytic performance of $\mathrm{TiO}_{2}-\mathrm{ZrO}_{2}$ composite layers prepared on CP Ti by micro arc oxidation method," Surface and Coatings Technology, vol. 307, pp. 554-564, 2016.

[17] N. D. Sakhnenko, M. V. Ved, and A. V. Karakurkchi, "Nanoscale oxide PEO coatings forming from diphosphate electrolytes," in Nanophysics, Nanomaterials, Interface Studies, and Applications, O. Fesenko and L. Yatsenko, Eds., pp. 159-184, Springer International Publishing, Basel, Switzerland, 2017.

[18] Y. Zhang, W. Fan, H. Q. Du, and Y. W. Zhao, "Microstructure and wearing properties of PEO coatings: effects of $\mathrm{Al}_{2} \mathrm{O}_{3}$ and $\mathrm{TiO}_{2}$," Surface Review and Letters vol. 25, no. 8, article 1850102, 2017.

[19] M. V. Ved', N. D. Sakhnenko, and K. V. Nikiforov, "Stability control of adhesional interaction in a protective coating/metal system," Journal of Adhesion Science and Technology, vol. 12, no. 2, pp. 175-183, 1998.

[20] V. V. Bykanova, N. D. Sakhnenko, and M. V. Ved', "Synthesis and photocatalytic activity of coatings based on the $\operatorname{Ti}_{x} \mathrm{Zn}_{y} \mathrm{O}_{z}$ system," Surface Engineering and Applied Electrochemistry, vol. 51, no. 3, pp. 276-282, 2015.

[21] M. V. Ved', N. D. Sakhnenko, A. V. Karakurkchi, M. V. Mayba, and A. V. Galak, "Synthesis and functional properties of mixed titanium and cobalt oxides," Advanced Functional Materials, vol. 24, no. 4, pp. 534-540, 2017.

[22] G. S. Yar-Mukhamedova, M. V. Ved, A. V. Karakurkchi, and N. D. Sakhnenko, "Mixed alumina and cobalt containing plasma electrolytic oxide coatings," IOP Conference Series: Materials Science and Engineering, vol. 213, p. 012020, 2017.

[23] J. Rumble, Handbook of Chemistry and Physics, CRC, Boca Raton, FL, USA, 98th edition, 2017.

[24] A. E. R. Friedemann, K. Thiel, U. Haßlinger, M. Ritterd, M. Gesing, and P. Plagemann, "Investigations into the structure of PEO-layers for understanding of layer formation," Applied Surface Science, vol. 443, pp. 467-474, 2018.

[25] A. Karakurkchi, M. Sakhnenko, M. Ved, A. Galak, and S. Petrukhin, "Application of oxide-metallic catalysts on valve metals for ecological catalysis," Eastern-European Journal of Enterprise Technologies, vol. 5, no. 10, pp. 12-18, 2017.

[26] N. Sakhnenko, M. Ved, and A. Karakurkchi, "Morphology and properties of coatings obtained by plasma-electrolytic oxidation of titanium alloys in pyrophosphate electrolytes alloys," Protection of Metals and Physical Chemistry of Surfaces, vol. 53, no. 6, pp. 1082-1090, 2017. 


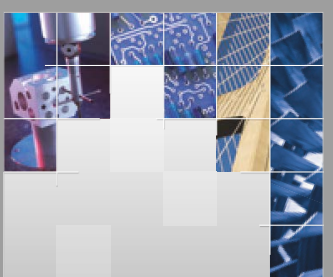

\section{Enfincering}
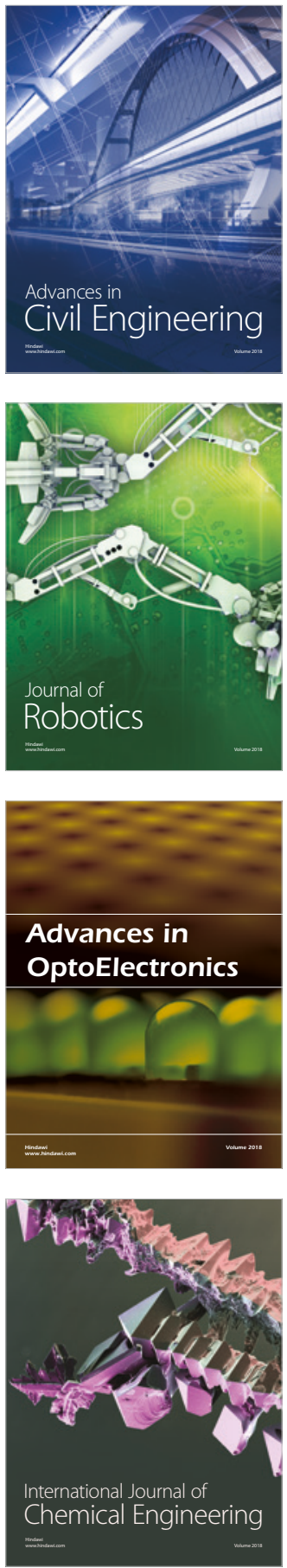

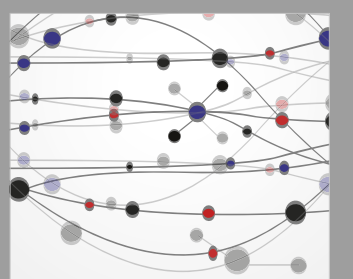

\section{Rotating \\ Machinery}

The Scientific World Journal

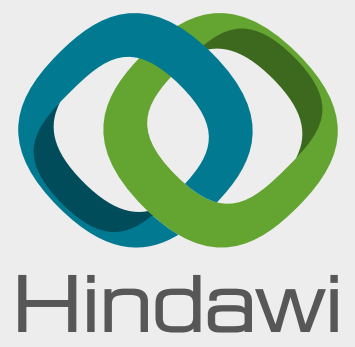

Submit your manuscripts at

www.hindawi.com
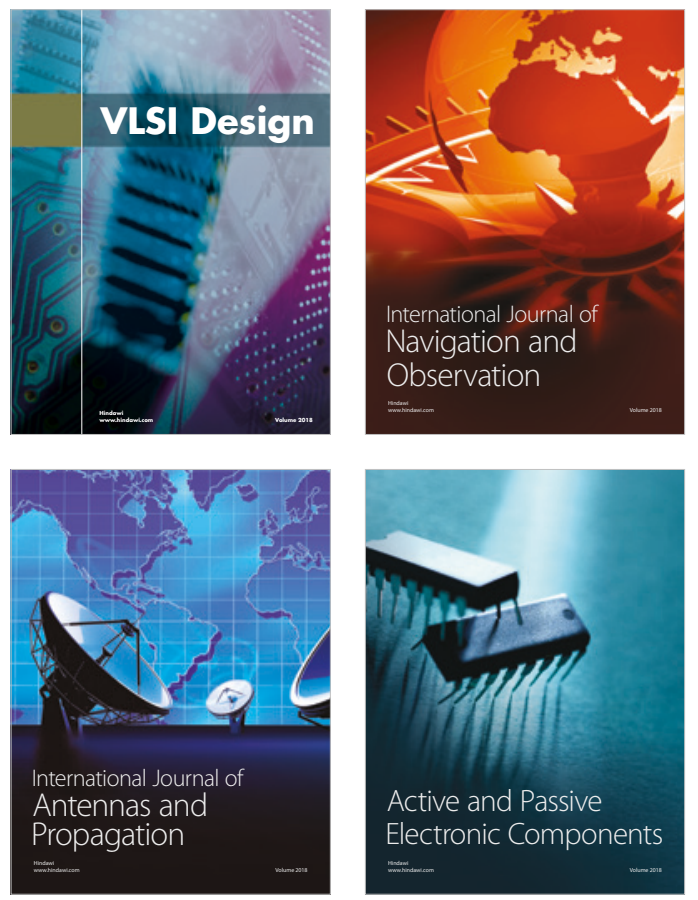
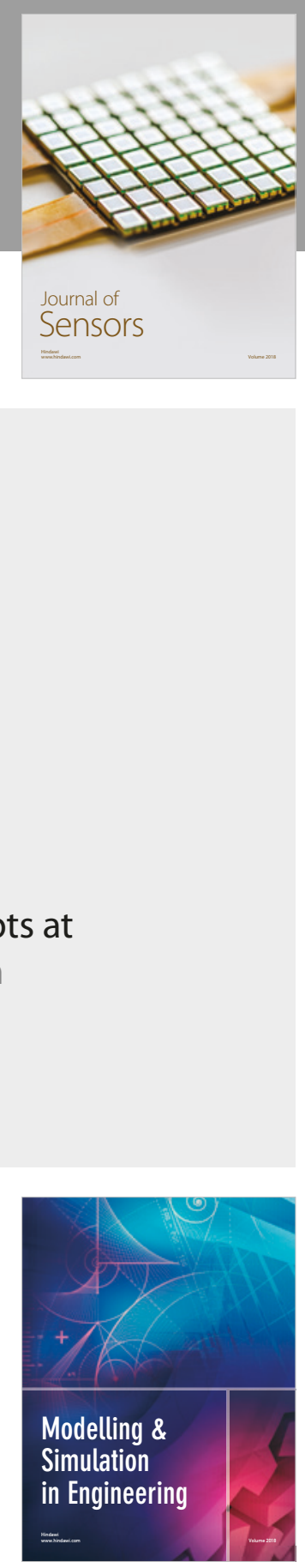

\section{Advances \\ Multimedia}
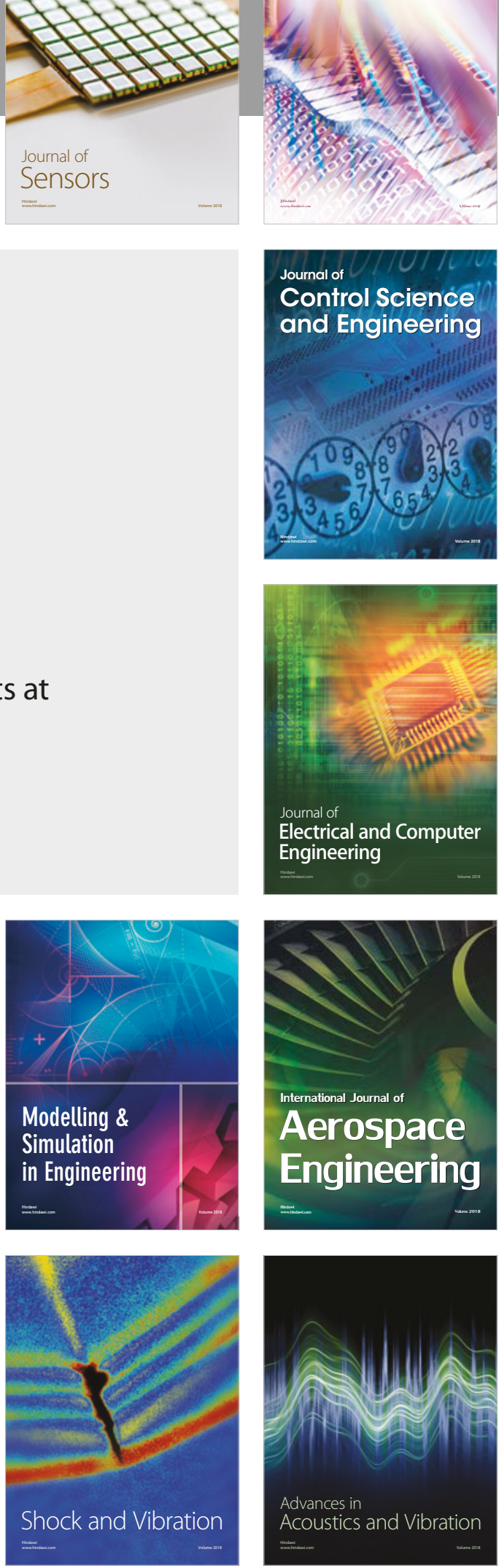